Lichenologist 34(4): 275-276 (2002)

doi:10.1006/lich.2001.0023, available online at http://www.idealibrary.com on IDE $\mathbf{l}^{\circledR}$

\title{
Hildur Krog: a birthday tribute
}

Professor Dr Philos. Hildur Krog celebrated her 80 th birthday on the 22 March this year. The first six articles in this issue of The Lichenologist are invited contributions from a selection of her academic associates and friends, dedicated to Hildur in recognition of her outstanding contributions to lichenology.
It was the Norwegian botanist Eilif Dahl (1916-93), himself a keen researcher of the Arctic lichen flora, who presented the young student Hildur Krog with a long list of possible dissertation subjects for a cand. real. thesis. She opted for the last one: to apply and evaluate the new "microchemical" methods developed by Asahina in the

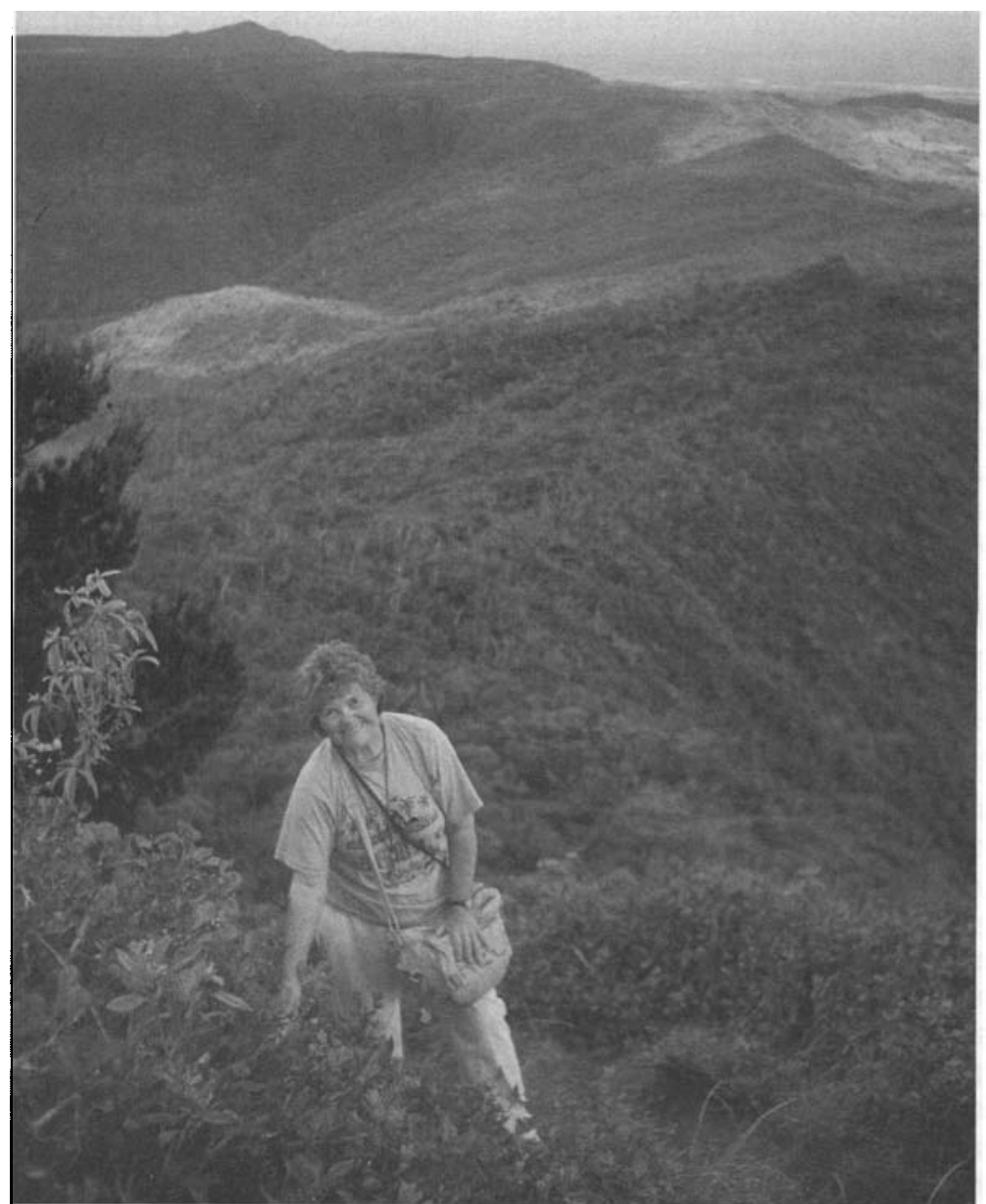

Hildur Krog at the type locality of Krogia coralloides (see p. 293), Mauritius, with Elfin Forest in the background, 1991, photo: E. Timdal. 
late 1930 s in a study of the taxonomic relationships in the parmelioid lichens of Norway. 'Microchemical Studies on Parmelia' was printed in December 1950. As is so often the case in a career in science, this very first work set the tone for what was to follow. A solid emphasis on the evidence to be derived from chemistry has characterized Hildur's work ever since, and also a particular fondness for anything exhibiting parmelioid growth form.

Accompanying her husband who studied extreme physiology (adaptations to cold climates), Hildur worked as a general biologist at the Arctic Health Research Center in Anchorage, Alaska, between 1950-54. This also gave her the opportunity to make extensive collections of the Alaskan lichen flora, resulting in her doctoral thesis 'The macrolichens of Alaska' (1968), published in the monograph series of the Norwegian Institute of Polar Research (No. 144). It was cold war times, and the field work was appropriately carried out with transport support from the Arctic Aeromedical Laboratory, Ladd Air Force Base, but also the US Fish and Wildlife Service. The work on the Alaskan lichens, including an extensive field trip in 1957, was also supported by the Norwegian Research Council, the Norwegian Foreign Office and a Fulbright grant. In her work on the Alaskan lichens Hildur Krog also enlisted the help of notable authorities such as Asahina, Degelius, Kurokawa, Lamb, Motyka, and Santesson.

In 1971 Hildur was appointed as curator of the lichen herbarium at the Botanical Museum, University of Oslo, a position she held until she retired in 1992. In 1987 she was given a personal professorship. At the museum she established a laboratory for lichen chemistry, and for many years taught a highly successful course in thin-layer chromatography (TLC), imposing her exacting standards of work and evidence on the young and meek. Hildur also led a course in lichen systematics with an associated field course to a number of typical Norwegian habitats.

In the early seventies, she turned her attention towards African lichens. A series of field trips from 1972 to 1996 resulted in a number of taxonomic papers on the macrolichen flora of East Africa, Macaronesia and the Mascarenes. The East African studies were often in company with T. D. V. Swinscow. They worked their way systematically through the genera, publishing revisions of the East African species at regular intervals. The results were summarized in the flora 'Macrolichens of East Africa', published in 1988 by the British Museum of Natural History. Hildur continued her African field trips and taxonomic studies after this flora, and published on rainforest lichens in Tanzania in 2000 and on African Phyllopsora species last year (with Einar Timdal).

Hildur has devoted much time to the study of Norwegian lichens. Her collecting trips covered much of the country, and the material consists of c. 2200 specimens. Scandinavian lichenologists are particularly thankful for her key to the Nordic macrolichens (with Eilif Dahl, 1973) and the Norwegian macrolichen flora (with Håvard Østhagen and Tor Tønsberg, 1980, 2nd ed. 1994). Hildur has also published several manuals on monitoring air pollution with lichens and for many years has been a highly regarded editor of the Norwegian fournal of Botany for many years.

Hildur Krog is a Fellow of the Norwegian Academy of Science and Letters. She received the Acharius medal from the International Association of Lichenologists (IAL) in 1992.

Three of Hildur's former students, now her colleagues, have signed this homage. We would like to emphasize that the present volume not only celebrates her distinguished work as a scientist, but also her enthusiasm and care as a supervisor who was most generous with her time and impressed us with her no-nonsense approach to research. On behalf of her friends and colleagues throughout the world, and of the editors and authors of this volume, we wish her joy in her science and continued good health!

\section{Geir Hestmark, Einar Timdal \&} Tor Tønsberg

Oslo and Bergen, July 2002 